\title{
PENERAPAN METODE PEMBELAJARAN JIGSAW SEBAGAI UPAYA MENINGKATKAN HASIL BELAJAR IPA PADA SISWA KELAS IV SD
}

\author{
Desak Kadek Sri Astiti 1,*, I Wayan Widiana ${ }^{2}$ \\ 1 Jurusan Pendidikan Guru Sekolah Dasar. Universitas Pendidikan Ganesha, Indonesia \\ 2 Jurusan Pendidikan Guru Sekolah Dasar. Universitas Pendidikan Ganesha, Indonesia
}

\begin{abstract}
Abstrak
Penelitian ini untuk mengetahui peningkatan hasil belajar siswa setelah penerapan jigsaw dalam pembelajaran IPA kelas IV SD No. 1 Sobangan. Jenis penelitian ini adalah penelitian tindakan kelas yang terdiri dari 2 siklus. Setiap siklus terdiri dari tahap perencanaan, pelaksanaan tindakan, observasi dan evaluasi, serta refleksi. Subjek penelitian ini adalah siswa kelas kelas IV SD No. 1 Sobangan tahun pelajaran 2016/2017 dengan jumlah siswa 17 orang. Data mengenai prestasi belajar mencakup data tentang hasil belajar siswa dalam pembelajaran. Data hasil belajar IPA dikumpulkan melalui tes berbentuk esay. Data-data yang dikumpulkan dianalisis menggunakan analisis deskriptif. Hasil penelitian menunjukkan bahwa metode jigsaw dapat meningkatkan hasil belajar IPA siswa kelas IV SD No. 1 Sobangan. Hal ini dapat dilihat terjadi peningkatan rata-rata skor aktivitas siswa pada siklus I adalah 13,04\% dengan kriteria cukup aktif meningkat menjadi 63,82\% dengan kriteria aktif pada siklus II. Hasil belajar IPA yaitu dari rata-rata skor hasil belajar IPA 43,47\% dengan kriteria kurang baik pada refleksi awal menjadi 65,21\% dengan kriteria cukup baik pada siklus I, kemudian meningkat menjadi 100\% dngan kriteria sangat baik pada siklus II. Data tersebut menunjukkan terjadi peningkatan hasil belajar sebesar $50,78 \%$

\author{
Keywords: \\ Metode Pembelajaran, \\ Jigsaw, Hasil Belajar
}

\section{Pendahuluan}

Belajar merupakan aktifitas mental dan fisik untuk menghasilkan perubahan, perubahan yang diharapkan ialah perubahan sikap, pengetahuan dan keterampiulan. Agar tercapainya perubahan tersebut, diharapkan siswa terlibat secara aktif. Disini ditekankan bahwa pembelajaran berpusat pada siswa dan guru hanya sebagai fasilitator dan moderator yang membimbing siswa kearah pembentukan pengetahuan oleh diri mereka sendiri. Pendidikan bertujuan membangun dan mengembangkan potensi peserta didik sehingga menjadi manusia yang berkualitas. Peran pendidikan sangat penting untuk menciptakan kehidupan yang cerdas, damai, terbuka dan demokratis. (Tirtaraharja dan S.L La Sulo, 2005).

Oleh karena itu, pembaruan dalam bidang pendidikan harus selalu dilaksanakan untuk meningkatkan kualitas pendidikan Nasional. Pendidikan merupakan prihal yang sangat penting dan akan terus berkembang seiring berjalannya jaman. Untuk meningkatkan mutu pendidikan di Indonesia, pemerintah pun sudah melakukan beberapa upaya, salah satunya adalah dengan memperbaiki kurikulum dan beberapa proyek perbaikan mutu, di antaranya proyek MPMBS (Manajemen Peningkatan Mutu Berbasis Sekolah), proyek perpustakaan, proyek BOMM (Bantuan Operasional Manajemen Mutu), proyek BIS (Bantuan Imbal Siswa), proyek peningkatan profesionalisme guru melalui pemberian tunjangan profesi, proyek pengadaan buku paket, proyek DBL (Dana Bantuan Langsung), BOS (Bantuan Operasional Sekolah).

Namun dalam kenyataannya kegiatan belajar mengajar di setiap sekolah belum mencapai sasaran sesuai dengan standar yang diharapkan oleh pemerintah. Proses belajar dan pembelajaran di sekolah belum mampu meningkatkan kreatifitas siswa karena pada proses pembelajaran di kelas masih banyak guru yang menyajikan materi bersifat konservatif dan terkadang menoton, sehingga pembelajaran masih berpusat pada guru, siswa hanya duduk, mencatat dan mendengarkan apa yang disampaikan oleh guru

\footnotetext{
* Corresponding author.

E-mail Addresses: desakmadesriastiti90@gmail.com (Desak Kadek Sri Astiti), wayan_widiana@yahoo.co.id (I Wayan Widiana)
} 
dan hal ini mengakibatkan pembelajaran menjadi tidak menarik dan membosankan bagisiswa, minat siswa pun jadi rendah di dalam mengikuti proses pembelajaran di kelas.

Berdasarkan gambaran di atas perlu kiranya motivasi dari guru untuk mengembangkan suatu model dan metode pembelajaran yang lebih inovatif dan menyenangkan dalam proses pembelajaran supaya bisa merangsang minat siswa untuk berpikir kreatif, aktif dan inovatif. Penerapan model pembelajaran koperatif dengan metode jigsaw rasanya tepat digunakan di dalam proses belajar mengajar di tingkat sekolah dasar pada mata pelajaran IPA. Untuk dapat meningkatkan sumber daya manusia, peran IPA sangatlah diperlukan karena IPA merupakan dasar dari teknologi. Oleh sebab Itu, mata pelajaran IPA wajib diajarkan di sekolah dasar. IPA di sekolah dasar hendaknya membuka kesempatan untuk memupuk rasa ingin tahu siswa secara ilmiah (Samatowa, 2010). Dalam proses pembelajaran IPA lebih menitik beratkan pada serangkaian proses penyelidikan tentang suatu konsep peristiwa yang terjadi di sekitar siswa. Di dalam proses inilah perlu usaha dari guru untuk menciptakan kondisi belajar yang bisa mengaktifkan siswa. Dalam pelaksanaan pembelajaran selalu menggunakan pendekatan IPA, ini artinya bahwa dalam setiap pelaksanaan pembelajaran harus terjadi kegaiatan interaksi siswa secara langsung dalam proses pembelajaran seperti mengamati, menghitung, mengukur, mengklasifikasikan, pengenalan, membuat hipotesis, merencanakan penelitian. Tujuan pembelajaran IPA adalah untuk melatih anak berfikir kritis dan objektif terhadap permasalahan secara alamiah (Samatowa, 2006). Pembelajaran IPA di sekolah dasar berpedoman pada perspektif kesuksesan dalam pembelajaran sehingga dilaksanakan berbagai upaya dalam menciptakan kesuksesan pembelajaran tersebut.

Menurut Purwanto (1989), menyatakan bahwa hasil belajar adalah suatu yang digunakan untuk menilai hasil pelajaran yang telah diberikan kepada siswa dalam waktu tertentu. Menurut Surahmad (1997) berpendapat hasil belajar adalah hasil dimana guru melihat bentuk akhir dari pengalaman interaktif edukatif yang diperlihatkan adalah menempatkan tingkah laku. Hasil belajar merupakan perilaku yang diperoleh pembelajar setelah mengalami aktifitas belajar (Chatarina, dkk, 2004).

Berdasarkan hasil observasi awal yang penulis laksanakan di SD Negeri 1 Sobangan, minat siswa terhadap mata pelajaran IPA masih sangat kecil, pada hal mata pelajaran IPA sangat penting bagi kehidupan kita sebagai manusia, melalui mata pelajaran IPA siswa dituntut untuk berpikir kritis, rasional dan menerapkan dali-dalil sain dalam sendi-sendi kehidupan, bahkan mata pelajaran IPA di ikut sertakan dalam ujian nasional. Data yang penulis dapatkan dari hasil pemetaan melalui angket pada siswa kelas IV SD Negeri 1 Sobangan dari 17 orang siswa, hanya 3 orang siswa yang suka terhadap mata pelajaran IPA dan 14 orang siswa menganggap mata pelajaran IPA tidak menarik sehingga mereka tidak menyukainya. Berdasarkan rendahnya minat siswa terhadap mata pelajaran IPA berimplikasi pada hasil nilai yang diperoleh siswa, rata-rata nilai kelas untuk mata pelajaran IPA di kelas III pada semester genap tahun pelajaran 2015/2016 hanya 75,45 dengan KKM 72, (legher, kelas IISD Negeri 1 Sobangan semester genap tahun pelajaran 2015/2016). Dengan 2 orang mendapat nilai diatas rata-rata,5 orang sesuai dengan ratarata, dan 10 orang dibawah rata-rata. Menurut Dimyati dan Moedjiono (1994) hasil belajar merupakan hasil dari suatu interaksi tindak mengajar atau tindak belajar. Sedangkan menurut Sudjana, (2005) hasil belajar adalah perubahantingkah laku yang dicapai siswa atau kemampuan-kemampuan yang dimiliki siswa setelah menerima pengalaman belajarnya.

Berdasarkan permasalahan di atas penulisan berinisiatif untuk mengadakan penelitian tindakan kelas, dalam rangka memperbaiki minat dan hasil belajar IPA siswa, menjadikan mata pelajaran IPA lebih menarik sehingga dapat merangsang minat siswa untuk lebih serius mengikuti pembelajaran dan menyukai pelajaran IPA. Oleh Karena Itu, Penulis Akan Melaksanakan Penelitian Tindakan Kelas Dengan Judul "Penerapan Metode Pembelajaran Jigsaw Sebagai Upaya Untuk Meningkatkan Hasil Belajar IPA Pada Siswa Kelas IV SD Negeri 1 Sobangan Semester Ganjil"

Model pembelajaran jigsaw adalah suatu tipe pembelajaran kooperatif yang terdiri dari beberapa anggota dalam suatu kelompok yang bertanggung jawab atas penguasaan bagian materi belajar dan mampu mengajarkan materi tersebut pada anggota kelompoknya yang lain (Arends, 1997). Menurut Nurkancana (2005) bahwa "model pembelajaran jigsaw adalah model pembelajaran dengan mengelompokkan siswa menjadi beberapa tim yang anggotanya terdiri dari 4 sampai 6 siswa dengan karakteristik yang heterogen". Menurut Isjoni (2007), "Pembelajaran kooperatif model Jigsaw merupakan salah satu tipe pembelajaran yang mendorong siswa aktif dan saling membantu dalam menguasai materi pembelajaran untuk mencapai prestasi yang maksimal".

Pembelajaran kooperatif tipe Jigsaw adalah suatu tipe pembelajaran Kooperatif yang terdiri dari beberapa anggota dalam satu kelompok yang bertanggung jawab atas penguasaan bagian materi belajar dan mampu mengajarkan materi tersebut kepada anggota lain dalam kelompoknya (Arends,1997). proses dalam Jigsaw akan menguntungkan semua anggota kelompok dengan memberikan keterampilan mengajari dan belajar dari teman sekelas (Reynolds 1997). Jigsaw lebih meningkatkan pengetahuan 
umum dan keterampilan dasar siswa yang dapat dideskripsikan sebagai berorientasi produk dan dihitung dengan tes kemampuan standar.Hasilnya berupa kemampuan (Kagan 1992).

Pembelajaran kooperatif jigsaw didasari oleh pemikiran filosofis "Getting Better Together" yang bararti untuk mendapatkan sesuatu yang lebih baik dalam belajar hendaknya dilakukan secara bersamasama. Dalam bukunya Muhammad Nur (1999) juga dijelaskan bahwa siswa lebih mudah menemukan dan memahami konsep-konsep yang sulit jika mereka saling mendiskusikan masalah tersebut dengan temanya. Hizyam Zaini,dkk,2007). Pembelajaran kooperatif tipe jigsaw ini memandang bahwa keberhasilan dalam belajar bukan semata-mata harus diperoleh oleh guru, melainkan bisa juga di pihak lain yang terlibat dalam pembelajaran itu, yaitu teman.

Menurut Rusman (2012) Pembelajaran model Jigsaw ini dikenal juga dengan kooperatif para ahli. Karena anggota setiap kelompok dihadapkan pada permasalahan yang berbeda. Tetapi permasalahan yang dihadapi setiap kelompok sama, setiap utusan dalam kelompok yang berbeda membahas materi yang sama, kita disebut tim ahli yang bertugas membahas permasalahan yang dihadapi, selanjutnya hasil permasalahan itu dibawa ke kelompok asal dan disampaikan pada anggota kelompoknya. Ibrahim (2000) menyatakan bahwa pada Jigsaw, kompetisi terjadi antar tim pembelajaran untuk memperoleh penghargaan kelompok khusus, berdasarkan penampilan individu.

\section{Metode}

Jenis penelitian yang digunakan dalam penelitian ini adalah penelitian tindakan kelas (PTK). Penelitian Tindakan Kelas merupakan pencermatan terhadap kegiatan belajar berupa sebuah tindakan, yang sengaja dimunculkan dan terjadi dalam sebuah kelas secara bersamaan (Arikunto, 2014). Menurut Supardi (dalam Arikunto, 2014) menyatakan bahwa "Penelitian Tindakan Kelas merupakan suatu penelitian yang akar permasalahannya muncul di kelas dan dirasakan langsung oleh guru yang bersangkutan".

Berdasarkan pendapat diatas maka Penelitian Tindakan adalah penelitian terhadap kegiatan belajar yang dilaksanakan pada sebuah kelas. Penelitian ini dilaksanakan di SD No. 1 Sobangan pada siswa kelas IV dengan jumlah siswa sebanyak 17 orang yang terdiri dari 7 siswa perempuan dan 10 siswa lakilaki. Secara mendetail Kemmis dan Taggart (hopkins, 1993) menjelaskan tahap-tahap penelitian tindakan yang dilakukannya. Permasalahan penelitian difokuskan kepada strategi bertanya kepada siswa dalam pembelajaran sains. Bagan pelaksanaan penelitian adalah sebagai berikut:

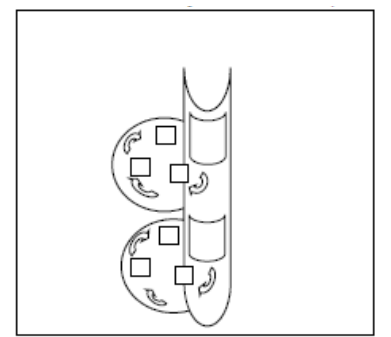

Gambar 1. Model Spiral dari Kemmis dan Taggart (dalam Prof. Dr. Rochiati Wiriaatmadja, 2008)

Penelitian ini dilaksanakan dalam model siklus, dimana pada setiap siklus terdiri dari 2 kali pertemuan, dua kali pertemuan untuk pelaksanaan .pembelajaran dan satu kali pertemuan untuk pelaksanaan tes. Siklus I terdiri atas 4 tahapan yaitu: 1) Tahap Perencanaan, kegiatan-kegiatan yang dilakukan pada tahap ini antara lain: a) Mensosialisasikan mengenai model pembelajaran Jigsaw kepada guru IPA kelas IV; b) Menganalisis kurikulum untuk menentukan standar kompetensi, kompetensi dasar dalam menyusun silabus yang akan digunakan dengan mengunakan model pembelajaran Jigsaw; c) Menyiapkan rencana pelaksanaan pembelajaran (RPP) yang menggunakan model pembelajaran Jigsaw. 2) Tahap Tindakan. 3) Tahapan Observasi/Evaluasi, Melaksanakan observasi bersamaan dengan proses tindakan. Observasi ini dilakukan untuk memperbaiki tindakan pembelajaran pada siklus berikutnya. Pada tahap ini guru juga melaksanakan evaluasi terhadap hasil belajar siswa yang dilaksanakan pada setiap pertemuan; 4) Tahap Refleksi, Refleksi dilakukan sebagai dasar memperbaiki dan menyempurnakan perencanaan serta pelaksanaan tindakan pada siklus berikutnya. Pada tahap ini guru juga melakukan evaluasi terhadap hasil belajar siswa yang dilaksanakan pada setiap pertemuan. 
Tabel 1 Tindakan yang dilakukan dalam penelitian

\begin{tabular}{|c|c|}
\hline Tahap Jigsaw & kegiatan \\
\hline $\begin{array}{l}\text { 1. Orientasi } \\
\text { Orientasi adalah langkah untuk membina } \\
\text { suasana atau iklim pembelajaran yang } \\
\text { responsif. }\end{array}$ & $\begin{array}{l}\text { Guru menyampaikan topik dan tujuan } \\
\text { pembelajaran. Guru menjelaskan pokok-pokok } \\
\text { kegiatan yang akan dilakukan oleh siswa. Guru } \\
\text { juga memberikan motivasi agar siswa lebih } \\
\text { bersemangatuntuk belajar. }\end{array}$ \\
\hline $\begin{array}{l}\text { 2. Merumuskan masalah } \\
\text { Merumuskan masalah merupakan langkah } \\
\text { membawa siswa pada suatu persoalan yang } \\
\text { mengandung teka-teki. }\end{array}$ & $\begin{array}{l}\text { Guru memberikan topic yang akan dipelajari, } \\
\text { guru membimbing siswa untuk merumuskan } \\
\text { masalah yang sesuai dengan topik. }\end{array}$ \\
\hline $\begin{array}{l}\text { 3. Merumuskan hipotesis } \\
\text { Merumuskan hipotesis merupakan langkah } \\
\text { untuk merumuskan jawaban sementara } \\
\text { dari permasalahan. }\end{array}$ & $\begin{array}{l}\text { Guru membimbing siswa untuk merumuskan } \\
\text { hipotesis dengan mengajukan berbagai } \\
\text { pertanyaan. }\end{array}$ \\
\hline $\begin{array}{l}\text { 4. Mengumpulkan data } \\
\text { Mengumpulkan data merupakan kegiatan } \\
\text { mengumpulkan informasi yang dibutuhkan } \\
\text { menguji hipotesis yang diajukan. }\end{array}$ & $\begin{array}{l}\text { Guru membimbing siswa untuk } \\
\text { mengumpulkan informasi } \\
\text { menyediakan sumber belajar. }\end{array}$ \\
\hline $\begin{array}{l}\text { 5. Menguji hipotesis } \\
\text { Menguji hipotesis adalah proses } \\
\text { menentukan jawaban yang diangap terima } \\
\text { sesuai dengan data atau informasi yang } \\
\text { diperoleh berdasarkan pengumpulan data. }\end{array}$ & $\begin{array}{l}\text { Siswa menguji hipotesis yang telah } \\
\text { dirumuskan dengan bimbingan guru. }\end{array}$ \\
\hline $\begin{array}{l}\text { 6. Merumuskan kesimpulan } \\
\text { Merumuskan kesimpulan adalah proses } \\
\text { mendeskripsikan temuan yang diperoleh } \\
\text { berdasarkan pengujian hipotesis. }\end{array}$ & $\begin{array}{l}\text { Berdasarkan data-data yang diperoleh dan } \\
\text { setelah menguji hipotesis siswa merumuskan } \\
\text { kesimpulan. }\end{array}$ \\
\hline
\end{tabular}

Pada dasarnya alur pelaksanaan siklus dua ini sama dengan siklus pertama, hanya saja pada siklus ke dua ini dilaksanakan perbaikan dari kekurangan-kekurangan yang ditemukan ketika melakukan refleksi pada siklus petama. Adapun alur pelaksanaan siklus kedua sebagai berikut: 1) Perencanaan, Halhal yang perlu disiapkan dalam perencanaan siklus dua ini sebagai berikut: a) Mengkaji silabus mata pelajaran IPA untuk mengetahui Standar kompetensi dan kompetensi dasar yang akan dipergunakan dalam pembelajaran; b) Menyiapkan skenario pembelajaran dan perencanaan pembelajaran, baik dalam bentuk rencana pembelajaran; c) Menyiapkan peralatan dan perlengkapan yang diperlukan pada saat pembelajaran; d) Menyusun perangkat instrumen penelitian, berupa lembar observasi dan tes hasil belajar. 2) Pelaksanaan Tindakan, Pada siklus II ini, diterapkan strategi dengan langkah-langkah pembelajaran yang sama pada siklus I.

Adapun langkah-langkah yang dilakukan adalah: a) Mengumumkan kelompok siswa yang dibentuk berdasarkan nilai hasil tes pada siklus I dengan beranggotakan 3-5 orang siswa pada masingmasing kelompok; b) Mengumumkan hasil yang didapat pada siklus I; c) Guru menyajikan atau menjelaskan materi pelajaran; d) Membagikan lembar kerja siswa mengenai materi dalam kehidupan sehari-hari; e) Belajar dalam kelompok: siswa mengerjakan LKS yang diberikan guru secara berkelompok melalui percobaan; f) Setelah waktu yang tersedia habis, guru menegaskan kembali konsep yang telah ditemukan dengan metode tanya jawab. 3) Observasi dan Evaluasi, Observasi dilaksanakan dalam setiap tindakan dalam siklus II, alat yang digunakan adalah lembar observasi. Siswa diobservasi mengenai aktivitas kelompok siswa di dalam kelas. Hasil observasi menunjukan bahwa kegiatan siswa sudah sesuai dengan tujuan yang diharapkan. Dengan demikian, hasil belajar siswa secara klasikal sudah melebihi target yang diharapkan. Hal ini diperoleh berdasarkan evaluasi hasil belajar siswa. Guru diobservasi dalam membuka pelajaran, menyampaikan materi dan menutup pelajaran dalam proses pembelajaran di kelas; 4) Refleksi, Relksi kembali dilaksanakan pada akhir siklus kedua, yang bertujuan untuk mengetahui keberhasilan yang telah dilakukan selama penelitian.

Penelitian ini dilakukan dengan proses kolaborasi dimana guru melakukan pembelajaran dan peneliti melakukan observasi dan menyiapkan sarana dan prasarana pembelajaran, maka peneliti melakukan observasi terhadap guru yang melakukan proses pembelajaran dimana metode obervasi dengan menggunakan instrumen berupa lembar observasi guru. Kemudian diadakan evaluasi terhadap hasil belajar siswa. Dalam hal ini, peneliti menggunakan metode dan instrumen pengumpulan data, yakni untuk 
mengetahui aktivitas siswa digunakan metode observasi dan instrumennya berupa lembar observasi. Sedangkan hasil belajar dengan menggunakan metode tes dan instrumen pengumpulan data berupa soal tes pilihan ganda. Analisis data dalam penelitian ini adalah menggunakan rumus statistik deskriptif. Statistik deskriptif adalah "bagian dari statistik yang mempelajari cara pengumpulan dan penyajian data sehingga mudah dipahami" (Iqbal Hasan, 2008). Rumus yang digunakan dalam analisis statistik deskriptif yakni sebagai berikut: 1) Menetukan Aktivitas dan Hasil Belajar Siswa, Aktivitas belajar siswa diamati dengan menggunakan lembar observasi. Sedangkan untuk mengetahui hasil belajar menggunakan tes berupa tes uraian. Data yang diperoleh kemudian dianalisis dengan menggunakan statistik deskriptif. Adapun rumus-rumus analisis deskriptif kuantitatif yang digunakan sebagai berikut:

a) Menghitung aktivitas dan hasil belajar siswa secara individu dapat menggunakan rumus sebagai berikut.

$$
\begin{aligned}
& \mathrm{P}=\frac{X}{S M I} \times 100 \\
& \text { Keterangan: } \\
& P=\text { Skor aktivitas dan hasil belajar siswa (individu) } \\
& X=\text { Skor aktivitas dan hasil belajar yang diperoleh siswa } \\
& S M i=\text { Skor maksimal ideal }
\end{aligned}
$$

b) Menghitung rata-rata aktivitas dan hasil belajar siswa secara klasikal dapat menggunakan rumus sebagai berikut.

$$
\mathrm{M}=\frac{\sum X}{N}
$$

Keterangan:

$\mathrm{M}=$ Mean/rata-rata aktivitas dan hasil belajar siswa secara klasikal

$\sum X=$ Jumlah skor aktivitas dan hasil belajar seluruh siswa

$N=$ Jumlah siswa

c) Menghitung persentase rata-rata aktivitas dan hasil belajar secara klasikal dapat menggunakan rumus sebagai berikut.

$$
\mathrm{M} \%=\frac{M}{S M i} \times 100 \%
$$

Keterangan:

$M \%=$ Rata-rata persentase skor aktivitas dan hasil belajar siswa

$M=$ Rata-rata skor aktivitas dan hasil belajar siswa

$S M i=$ Skor Maksimal ideal

Selanjutnya, tingkat keberhasilan tentang aktivitas dan hasil belajar siswa pada pelajaran IPA, dianalisis dengan membandingkan (M\%) atau persentase rata-rata aktivitas dan belajar siswa ke dalam PAP skala 5 dengan kriteria yang dapat disajikan pada tabel berikut:

Tabel 2 Pedoman Konversi PAP Skala 5 Aktivitas Belajar Siswa Mata Pelajaran IPA

\begin{tabular}{ccc}
\hline No. & Rentangan skor $(\%)$ & Kategori \\
\hline 1 & $85-100$ & Sangat aktif \\
2 & $75-84$ & Aktif \\
3 & $65-74$ & Cukup aktif \\
4 & $45-64$ & Kurang aktif \\
5 & $0-44$ & Sangat kurang aktif \\
\hline
\end{tabular}

Penelitian tindakan kelas untuk mengetahui aktivitas belajar siswa ini dikatakan memiliki aktivitas baik apabila aktivitas belajar siswa minimal berada pada kategori cukup aktif, baik secara individu maupun klasikal.

Tabel 3 Pedoman Konversi PAP Skala 5 Hasil Belajar Siswa Mata Pelajaran IPA

\begin{tabular}{ccc}
\hline Rentangan skor $(\%)$ & Kategori & Keterangan \\
\hline $85-100$ & Sangat aktif & Tuntas \\
$75-84$ & Aktif & Tuntas \\
$65-74$ & Cukup aktif & Tuntas \\
$45-64$ & Kurang aktif & Tidak Tuntas \\
$0-44$ & Sangat kurang aktif & Tidak Tuntas \\
\hline
\end{tabular}

Analisis Ketuntasan Belajar Siswa, Kriteria keberhasilan pelaksanaan tindakan ini berpedoman pada kriteria sebagai berikut: 1) Aktivitas siswa dalam pembelajaran dikatakan baik apabila aktivitas 
belajar berada pada katagori aktif; 2) Siswa dinyatakan tuntas jika sudah mampu memperoleh nilai Kriteria Ketuntasan Minimal (KKM) belajar secara individu yaitu 73. Secara klasikal, siswa dinyatakan tuntas apabila 75\% dari jumlah siswa keseluruhan yang ada di kelas memperoleh nilai 73 ke atas.

\section{Hasil Dan Pembahasan}

Pada tahap refleksi awal, peneliti mencari data tentang hasil belajar kelas IV pada mata pelajaran IPA dengan materi panca indra. Pencarian nilai ini dimaksudkan untuk mengetahui hasil belajar IPA sebelum tindakan dan sebagai skor awal. Data ini digunakan untuk lebih menguatkan hasil observasi dan wawancara yang telah dilakukan, bahwa di kelas tersebut hasil belajar IPA siswa masih cukup rendah. Data nilai tes ulangan harian siswa pada mata pelajaran IPA+ juga digunakan untuk mengetahui skor kemajuan individu. Guru memberikan tes berupa soal esay yang berjumlah 5 soal. Masing-masing soal diberi bobot 2 Dengan kata lain apabila jawaban siswa benar maka diberi skor 2, apabila jawaban siswa salah diberi skor 0. Sebelum menghitung hasil belajar yang diperoleh siswa, terlebih dahulu menghitung skor yang diperoleh atau menghitung jumlah jawaban benar. Pencarian skor ini dimaksud untuk mengetahui hasil refleksi awal pada mata pelajaran IPA. Secara rinci hasil belajar yang diperoleh setiap siswa adalah sebagai berikut

Tabel 4 Skor Refleksi Awal tentang Hasil Belajar

\begin{tabular}{clccc}
\hline No & \multicolumn{1}{c}{ Nama } & Skor Siswa & Predikat & Keterangan \\
\hline 1 & Hordinaya & 30 & Sangat Kurang & Tidak Tuntas \\
2 & Adi Candra Wiguna & 75 & Baik & Tuntas \\
3 & Agus Aditya Gunawan & 50 & Kurang & Tidak Tuntas \\
4 & Ani Mulya Dewi & 50 & Kurang & Tidak Tuntas \\
5 & Andre Praditya Pratama & 40 & Kurang & Tidak Tuntas \\
6 & Ayu Pratiwi & 60 & Cukup & Tidak Tuntas \\
7 & Ayu Risna Dewi & 30 & Sangat Kurang & Tidak Tuntas \\
8 & Bintang Cahya Sari & 80 & Baik & Tuntas \\
9 & Ayu Chelsea Melati & 40 & Kurang & Tidak Tuntas \\
10 & Candra Pratama & 30 & Sangat Kurang & Tidak Tuntas \\
11 & Diki Ananda & 80 & Baik & Tuntas \\
12 & Echa Lisa Cahyani & 80 & Baik & Tuntas \\
13 & Mahendra Putra & 40 & Kurang & Tidak Tuntas \\
14 & Nila Lorensya & 40 & Kurang & Tidak Tuntas \\
15 & Rosalina Utari & 40 & Kurang & Tidak Tuntas \\
16 & Tiara Sinta Dewi & 30 & Sangat Kurang & Tidak Tuntas \\
17 & Dea Ananda Putri & 75 & Baik & Tuntas \\
\hline
\end{tabular}

Dengan membaca tabel di atas dapat diketahui bahwa rata-rata persen (M\%) sebesar 51,18\% dengan kata lain 12 siswa mendapat nilai < 70 dan 5 siswa mendapat nilai $\geq 70$. Artinya, sebagian besar siswa belum mencapai kriteria ketuntasan minimal. Data tersebut tergolong kategori rendah karena terletak pada tingkat penguasan materi secara klasikal diantara 40\%-54\% Dengan melihat skor hasil belajar IPA siswa sebelum tindakan, maka persentase mengenai hasil belajar IPA siswa sebelum tindakan dapat disajikan pada tabel di bawah ini.

Tabel 5 Persantase Ketuntasan Belajar Siswa Pada Refleksi Awal

\begin{tabular}{llllll}
\hline No. & Kategori & Jmlh & Persentase & Akreditas Kelulusan & $\begin{array}{l}\text { Siswa Tuntas/ } \\
\text { Tidak Tuntas }\end{array}$ \\
\hline 1 & Sangat tinggi & - & - & - & - \\
2 & Tinggi & 5 & $43,47 \%$ & $43,47 \%$ & Tuntas \\
3 & Sedang & 1 & $4.34 \%$ & - & Tidak Tuntas \\
4 & Rendah & 7 & $34,78 \%$ & - & Tidak Tuntas \\
5 & Sangat rendah & 4 & $17,39 \%$ & - & Tidak Tuntas \\
\hline Jumlah & 17 & $100 \%$ & $43,47 \%$ & \\
\hline
\end{tabular}

Berdasarkan hasil observasi yang dilakukan oleh peneliti selaku observator terhadap proses pembelajaran pada siklus I didapatkan data sebagai berikut: 5 orang siswa $(8,82 \%)$ berada dalam kategori tingkat aktivitas yang aktif, 1 orang siswa (23,53\%) berada dalam kategori tingkat aktivitas cukup aktif, 7 $(50 \%)$ orang berada dalam kategori tingkat aktivitas kurang aktif, dan 4 orang siswa $(17,65 \%)$ berada 
dalam kategori tingkat aktivitas sangat kurang aktif. Setelah mendapatkan data aktivitas belajar siklus 1 pada 17 orang siswa kelas IV semester 1 SD No. 1 Sobangan Data tersebut diperoleh rata-rata aktivitas belajar siswa sebesar 51,83\% atau berada dalam kategori tingkat aktivitas yang cukup aktif. Data aktivitas belajar siswa pada siklus I dapat dilihat pada tabel di bawah ini.

Tabel 6 Persentase Aktivitas Belajar Siklus I

\begin{tabular}{lllll}
\hline No & Kategori & Rentang Nilai & Jumlah Siswa & $\begin{array}{l}\text { Jumlah } \\
\text { Siswa Tuntas }\end{array}$ \\
\hline 1 & Sangat Aktif & $\overline{\mathrm{x}} \geq 90,00 \%$ & - & \\
2 & Aktif & $70,00 \% \leq \overline{\mathrm{x}}<90,00 \%$ & 3 & \\
3 & Cukup Aktif & $50,00 \% \leq \overline{\mathrm{x}}<70,00 \%$ & 4 & 13,04 \\
4 & Kurang Aktif & $30,00 \% \leq \overline{\overline{\mathrm{x}}}<50,00 \%$ & 10 & \\
5 & Sangat Kurang Aktif & $\overline{\mathrm{x}}<30,00 \%$ & - & \\
\hline Jumlah & & 17 & \\
\hline
\end{tabular}

Penelitian mengenai aktivitas belajar siswa dilanjutkan pada siklus 2 karena aktivitas siswa secara klasikal belum mencapai target minimal terletak pada kategori aktif. Setelah diadakan penilaian hasil belajar sebelum tindakan, ternyata diperoleh hasil yang kurang sesuai dengan harapan. Oleh karena itu, peneliti menerapkan pembelajaran dengan menerapkan metode jigsaw. Untuk mengukur hasil belajar siswa, dilakukan dengan teknik tes. Peneliti memberi soal esay berjumlah 5 butir soal. Setiap soal diberi bobot 2. Artinya, apabila jawaban benar diberi skor 2 dan apabila jawaban salah diberi skor 0. Jadi, skor maksimal ideal soal berjumlah 10. Skor hasil tes yang diperoleh siswa

Sebelum menghitung hasil belajar yang diperoleh siswa, terlebih dahulu menghitung skor yang diperoleh atau menghitung jumlah jawaban benar. Pencarian skor ini dimaksud untuk mengetahui hasil belajar IPA siklus I. Secara rinci hasil belajar yang diperoleh setiap siswa adalah sebagai berikut.

Table 7 Data Hasil Belajar Siklus I

\begin{tabular}{lll}
\hline No & Nama & Skor Siswa \\
\hline 1 & Hordinaya & 50 \\
2 & Adi Candra Wiguna & 75 \\
3 & Agus Aditya Gunawan & 50 \\
4 & Ani Mulya Dewi & 50 \\
5 & Andre Praditya Pratama & 60 \\
6 & Ayu Pratiwi & 60 \\
7 & Ayu Risna Dewi & 50 \\
8 & Bintang Cahya Sari & 80 \\
9 & Ayu Chelsea Melati & 50 \\
10 & Candra Pratama & 75 \\
11 & Diki Ananda & 80 \\
12 & Echa Lisa Cahyani & 80 \\
13 & Mahendra Putra & 50 \\
14 & Nila Lorensya & 75 \\
15 & Rosalina Utari & 50 \\
16 & Tiara Sinta Dewi & 75 \\
17 & Dea Ananda Putri & 75 \\
\hline Jumlah & 1085 \\
\hline
\end{tabular}

Jadi rata-rata aktivitas belajar siswa kels IV adalah 63,82. Menentukan hasil belajar siswa, untuk menentukan tingkat hasil belajar siswa dapat dihitung dengan membandingkan rata-rata persen (M\%) dengan kriteria Penilaian Acuan Patokan (PAP) skala lima. Dengan membaca tabel 4.5 dapat diketahui bahwa rata-rata persen (M\%) sebesar $63,82 \%$ dengan kata lain 8 orang siswa telah dinyatakan tuntas atau mendapat nilai $\geq 70$ dan 9 orang siswa belum dinyatakan belum tuntas atau mendapat nilai $<70$. Data tersebut tergolong kategori sedang karena terletak pada tingkat penguasan materi secara klasikal berada pada rentang ketuntasan individu antara 55\%-69\% (sesuai dengan tabel 3.3). Dengan melihat skor hasil belajar IPA siswa pada siklus I, maka persentase mengenai hasil belajar IPA siswa pada siklus I dapat disajikan pada tabel berikut 
Tabel 8 Persentase Kategori Ketuntasan Hasil Belajar Siklus I

\begin{tabular}{|c|c|c|c|c|c|c|}
\hline No & Kategori & Jml & Persentase & Akreditas Kelulusan & $\begin{array}{l}\text { SiswaTuntas/ } \\
\text { Tidak Tuntas }\end{array}$ & Ket \\
\hline 1 & Sangat tinggi & - & - & - & - & \multirow{6}{*}{$\begin{array}{l}\text { Belum mencapai } \\
\text { target minimal } \\
70 \% \text { maka } \\
\text { dilanjutkan ke } \\
\text { Siklus II }\end{array}$} \\
\hline 2 & Tinggi & 8 & $65,21 \%$ & $65,21 \%$ & Tuntas & \\
\hline 3 & Sedang & 2 & $30,43 \%$ & - & Tidak tuntas & \\
\hline 4 & Rendah & 7 & $4,34 \%$ & - & Tidak tuntas & \\
\hline 5 & $\begin{array}{l}\text { Sangat } \\
\text { Rendah }\end{array}$ & - & - & - & - & \\
\hline \multicolumn{2}{|c|}{ Jumlah } & 17 & $100 \%$ & $65,21 \%$ & - & \\
\hline
\end{tabular}

Dilihat dari hasil aktivitas dan hasil belajar siswa terhadap pelaksanaan tindakan pada siklus I, terlihat adanya berbagai kekurangan maupun kendala-kendala yang muncul dalam proses pelaksanaannya. Kendala-kendala tersebut disebabkan oleh beberapa hal yaitu: (1) siswa belum terbiasa berdiskusi dalam menyelesaikan tugas yang diberikan. Hal ini disebabkan oleh kebiasaan siswa yang hanya sebagai pendengar dan pencatat selama proses pembelajaran. Faktor lain yang juga berpengaruh terhadap antusiasme siswa dalam berdiskusi adalah karena satu sama lain merasa bukan teman dekatnya. (2) siswa belum terbiasa dalam melaksanakan diskusi maupun tanya jawab dan masih malu untuk bertanya. (3) siswa masih memiliki sifat egosentris dan merasa dirinya lebih baik dari temannya. (4) tidak semua siswa turut aktif dalam mengerjakan tugas yang diberikan dan mereka cenderung hanya mengandalkan seorang temannya untuk mengerjakan tugas tersebut. (5) kurangnya jumlah media yang dipergunakan.

Bertolak dari kekurangan-kekurangan yang dihadapi pada siklus I, peneliti bersama dengan guru mendiskusikan perbaikan tindakan untuk selanjutnya diterapkan pada siklus II. Perbaikan yang dilakukan diantaranya: (1) meningkatkan bimbingan dan motivasi yang dilakukan oleh guru mengenai materi yang diajarkan, (2) merancang pencana pembelajaran yang lebih baik, (3) menambah jumlah media yang dipergunakan. Data aktivitas belajar siswa siklus II diperoleh sama dengan pelaksanaan siklus I yaitu, dengan menggunakan metode observasi terhadap kemunculan indikator aktivitas belajar sesuai dengan yang tertera pada lembar observasi. Berdasarkan hasil observasi yang dilakukan oleh peneliti terhadap proses pembelajaran pada siklus II didapatkan data sebagai berikut: 13 orang siswa (78,26\%) berada dalam kategori tingkat aktivitas yang aktif, sedangkan 4 orang siswa $(21,74 \%)$ berada dalam kategori tingkat aktivitas cukup aktif. Data aktivitas belajar siswa pada siklus II dapat dilihat pada tabel di bawah ini:

Tabel 9 Data Aktivitas Belajar Siklus II

\begin{tabular}{|c|c|c|c|c|}
\hline No. & Kategori & Rentang Nilai & $\begin{array}{l}\text { Jumlah } \\
\text { Siswa }\end{array}$ & $\begin{array}{l}\text { Jumlah Persentase } \\
\text { Siswa Tuntas }\end{array}$ \\
\hline 1 & Sangat Aktif & $\overline{\mathrm{x}} \geq 90,00 \%$ & - & \multirow{6}{*}{$63,82 \%$} \\
\hline 2 & Aktif & $70,00 \% \leq \overline{\mathrm{x}}<90,00 \%$ & 8 & \\
\hline 3 & Cukup Aktif & $50,00 \% \leq \bar{x}<70,00 \%$ & 9 & \\
\hline 4 & Kurang Aktif & $30,00 \% \leq \overline{\bar{x}}<50,00 \%$ & - & \\
\hline 5 & Sangat Kurang Aktif & $\overline{\mathrm{x}}<30,00 \%$ & - & \\
\hline \multicolumn{2}{|c|}{ Jumlah } & & 17 & \\
\hline
\end{tabular}

Rata-rata aktivitas belajar siswa pada siklus II adalah $(X)$ 63,82\%. Bila dikonversikan ke dalam penggolongan aktivitas belajar siswa berada pada rentang $70 \% \leq \bar{X}<90 \%$ atau berada dalam kategori aktif. Berdasarkan hasil tersebut, maka penelitian ini dihentikan. Karena tingkat aktivitas siswa secara klasikal telah mencapai target ketuntasan minimal yakni berkategori aktif. Setelah dilaksanakan tindakan siklus II peneliti kembali mengukur hasil belajar siswa. Peneliti memberi soal esay berjumlah 5 butir soal. Setiap soal diberi bobot 2. Artinya, apabila jawaban benar diberi skor 2 dan apabila jawaban salah diberi skor 0. Sebelum menghitung hasil belajar yang diperoleh siswa, terlebih dahulu menghitung skor yang diperoleh atau menghitung jumlah jawaban benar. Dengan teknik analisis tersebut, peneliti menentukan hasil belajar yang diperoleh siswa setelah diberi tes hasil belajar. Adapun hasil belajar yang diperoleh setiap siswa setelah diadakan tindakan siklus II dipaparkan sebagai berikut: 
Table 10 Data Hasil Belajar Siklus II

\begin{tabular}{lll}
\hline No & Nama & Skor Siswa \\
\hline 1 & Hordinaya & 70 \\
2 & Adi Candra Wiguna & 80 \\
3 & Agus Aditya Gunawan & 70 \\
4 & Ani Mulya Dewi & 70 \\
5 & Andre Praditya Pratama & 75 \\
6 & Ayu Pratiwi & 75 \\
7 & Ayu Risna Dewi & 70 \\
8 & Bintang Cahya Sari & 85 \\
9 & Ayu Chelsea Melati & 70 \\
10 & Candra Pratama & 75 \\
11 & Diki Ananda & 90 \\
12 & Echa Lisa Cahyani & 80 \\
13 & Mahendra Putra & 70 \\
14 & Nila Lorensya & 75 \\
15 & Rosalina Utari & 70 \\
16 & Tiara Sinta Dewi & 75 \\
17 & Dea Ananda Putri & 80 \\
\hline Jumlah & 1280 \\
\hline
\end{tabular}

Menentukan hasil belajar siswa, untuk menentukan tingkat hasil belajar siswa dapat dihitung dengan membandingkan rata-rata persen (M\%) dengan kriteria Penilaian Acuan Patokan (PAP) skala lima. Dengan membaca tabel 4.5 dapat diketahui bahwa rata-rata persen (M\%) sebesar 75,29\% dengan kata lain 17 orang siswa telah tuntas. Artinya, seluruh siswa tersebut telah mencapai kriteria ketuntasan minimal. Data tersebut tergolong kategori tinggi karena terletak pada tingkat penguasan materi secara klasikal berada pada rentang ketuntasan antara 70\%- 84\% (sesuai dengan tabel 3.3). Dengan melihat skor hasil belajar IPA siswa pada siklus I, maka persentase mengenai hasil belajar IPA siswa pada siklus I dapat disajikan pada tabel berikut.

Tabel 11 Persentase Katagori Ketuntasan Hasil Belajar IPA Siswa Kelas IV SD N. 1 Sobangan pada Siklus II

\begin{tabular}{lllllllr}
\hline No & Kategori & Jml & Persentase & $\begin{array}{l}\text { Akreditas } \\
\text { Kelulusan }\end{array}$ & $\begin{array}{l}\text { SiswaTuntas/ } \\
\text { Tidak Tuntas }\end{array}$ & Ket & \\
\hline 1 & Sangat tinggi & 5 & $26,08 \%$ & $26,08 \%$ & Tuntas & Telah mencapai \\
2 & Tinggi & 12 & $73,92 \%$ & $73,92 \%$ & Tuntas & target & diatas \\
3 & Sedang & - & - & - & - & kentuntasan \\
4 & Rendah & - & - & - & - & minimal 70\% maka \\
5 & Sangat Rendah & - & - & - & - & penelitian \\
dihentikan
\end{tabular}

Berdasarkan data tersebut di atas, maka dapat disimpulkan bahwa ketuntasan hasil belajar IPA pada materi panca indra dalam penelitian tindakan kelas siklus II yang memperoleh nilai sangat tinggi 5 orang $(26,09 \%)$ dan nilai tinggi 12 orang $(73,91)$. Secara klasikal, tingkat penguasaan materi sumber daya alam mencapai target sebesar 77,82\% dan berada pada rentang ketuntasan antara 70\%- 84\% dengan kategori tinggi (tabel 10). Berdasarkan hasil tersebut, maka penelitian ini dihentikan. Hal ini dikarenakan tingkat penguasan materi secara klasikal telah mencapai target diatas ketuntasan minimal 70\%.

Dengan memperhatikan aktivitas dan hasil belajar siswa siklus I dengan siklus II, ternyata pada siklus II menunjukkan peningkatan yang signifikan. Peningkatan aktivitas belajar siswa $(X)$ dari pada siklus I sebesar 13,04\% menjadi 63,82\% pada siklus II. Serta peningkatan ketuntasan belajar (M\%) dari siklus pada siklus I sebesar $67,60 \%$ menjadi $77,82 \%$ pada siklus II. Data tersebut menunjukkan terjadi peningkatan aktivitas belajar sebesar $(X)$ 23,74\% dan peningkatan hasil belajar sebesar (M\%) 10,22\%. Hal ini berarti aktivitas dan hasil belajar telah mencapai target yang direncanakan sebelumnya, maka penelitian ini dihentikan.

Berdasarkan hasil penelitian di atas, persentase aktivitas siswa $(X)$ sebesar 13,04\% dan hasil belajar IPA siswa mengenai materi panca indra pada akhir siklus I diperoleh persentase sebesar (M\%) $67,60 \%$. Hasil yang diperoleh ini tentu saja belum memenuhi target yang diharapkan, yaitu mengenai aktivitas minimal ketuntasan klasikal maupun individual belum mencapai kategori aktif. Untuk 
ketuntasan hasil belajar belum mencapai minimal 70\%. Sehingga, perlu dilakukan perbaikan dalam pelaksanaan pembelajaran siklus selanjutnya.

Dilihat dari hasil refleksi terhadap pelaksanaan tindakan pada siklus I, terlihat adanya berbagai kekurangan maupun kendala-kendala yang muncul dalam proses pelaksanaannya. Kendala-kendala tersebut disebabkan oleh beberapa hal yaitu: (1) siswa belum terbiasa berdiskusi dalam menyelesaikan tugas yang diberikan. Hal ini disebabkan oleh kebiasaan siswa yang hanya sebagai pendengar dan pencatat selama proses pembelajaran. Faktor lain yang juga berpengaruh terhadap antusiasme siswa dalam berdiskusi adalah karena satu sama lain merasa bukan temanm dekatnya. (2) siswa belum terbiasa dalam melaksanakan diskusi maupun tanya jawab dan masih malu untuk bertanya. (3) siswa masih memiliki sifat egosentris dan merasa dirinya lebih baik dari temannya. (4) tidak semua siswa turut aktif dalam mengerjakan tugas yang diberikan dan mereka cenderung hanya mengandalkan seorang temannya untuk mengerjakan tugas tersebut. (5) kurangnya jumlah media yang dipergunakan.

Bertolak dari kekurangankekurangan yang dihadapi pada siklus I, peneliti bersama dengan guru mendiskusikan perbaikan tindakan untuk selanjutnya diterapkan pada siklus II. Perbaikan yang dilakukan diantaranya: (1) meningkatkan bembibingan dan motivasi yang dilakukan oleh guru mengenai materi yang diajarkan, (2) merancang perencanaan pembelajaran yang lebih baik, (3) menambah jumlah media yang digunakan. Berdasarkan hasil pelaksanaan siklus II, yang merupakan perbaikan tindakan pada siklus I. Dari tes hasil belajar IPA siswa mengenai materi panca indra pada akhir siklus II. Kategori hasil belajar siswa (M\%) mengalami peningkatan sebesar $10,22 \%$ dari $67,60 \%$ pada siklus I menjadi $77,82 \%$ pada siklus II. Untuk aktivitas belajar siswa $(X)$ mengalami peningkatan sebesar $50,78 \%$ dari pada siklus I sebesar $13,04 \%$ menjadi $63,82 \%$ pada siklus II.

Dengan demikian, pencapaian aktivitas dan hasil belajar IPA siswa mengenai materi panca indra sudah sesuai dengan kriteria yang diharapkan. Mengenai aktivitas belajar siswa sudah mecapai ketuntasan minimal yang diharapkan yakni tergolong dalam kategori aktif. Untuk hasil belajar siswa sudah mencapai kriteria yang diharapkan. Terjadinya peningkatan hasil belajar IPA siswa mengenai panca indra dikarenakan siswa sudah mampu menguasai materi pembelajaran yang telah diterapkan oleh guru. Sebagian besar siswa telah serius dalam diskusi kelompok, sehingga diskusi dalam kelompok dapat berjalan dengan baik.

Secara umum, pada pelaksanaan tindakan siklus II tidak lagi muncul kendalakendala seperti pada siklus I. Siswa sudah terbiasa dan telah terlatih belajar dengan mengikuti penerapan pembelajaran dengan menggunakan media benda konkrit. Hal ini terlihat dari kegiatan yang dilakukan siswa telah menunjukkan keantusiasan dalam mengikuti pembelajaran yang dilaksanakan. Antara siswa sudah saling membantu dalam diskusi kelompok. Dalam pelaksanaan siklus II ini sebagian besar siswa sudah berani mengajukan pertanyaan, mengemukakan pendapat dan menanggapi pertanyaan dari guru dan temannya. Seperti yang telah disebutkan di atas, tentunya hal ini menyebabkan aktivitas maupun hasil belajar IPA siswa mengenai materi panca indra meningkat dari siklus sebelumnya.

Pembelajaran dengan menggunakan benda konkrit menuntut siswa agar tidak hanya menerima materi yang diberikan tetapi menemukan konsep dari materi yang diberikan. Melalui teknik ini, siswa diberi kesempatan untuk berbagi hasil dan informasi dengan kelompoknya. Akibatnya, siswa dituntut untuk selalu aktif dalam menggali suatu informasi dan pengetahuan dari berbagai sumber, baik dari bukubuku sumber yang relevan, diskusi maupun tanya jawab bersama teman satu kelompok, ataupun guru. Ini berarti, siswa aktif menggali pengetahuan sendiri, sehingga pemahaman konsep, kemampuan penalaran dan komunikasi,serta pemecahan masalah siswa dapat ditingkatkan yang nantinya berimbas juga pada peningkatan aktivitas maupun hasil belajar IPA siswa. Dari paparan di atas, secara umum telah mampu menjawab rumusan masalah. Penelitian ini dapat dikatakan berhasil, karena semua kriteria yang ditetapkan telah terpenuhi. Jadi, dapat disimpulkan bahwa penerapan media benda konkrit dapat meningkatkan aktivitas dan hasil belajar IPA siswa kelas IV SD No. 1 Sobangan tahun pelajaran $2016 / 2017$.

\section{Simpulan Dan Saran}

Berdasarkan rumusan masalah, hasil penelitian, dan pembahasan maka dapat disimpulkan halhal sebagai berikut: 1) Penerapan metode jigsaw dapat meningkatkan hasil belajar IPA pada siswa kelas IV SD No. 1 Sobangan tahun pelajaran 2016/2017. Hal ini dapat dilihat dari rata-rata persentase aktivitas belajar siswa pada siklus I sebesar $13,04 \%$ yang berada dalam kategori cukup aktif dan mengalami peningkatan sebesar 50,78\% pada siklus II menjadi 63,82\% berada pada kategori aktif; 2) Penerapan metode jigsaw dapat meningkatkan hasil belajar IPA pada siswa kelas IV SD No. 1 Sobangan tahun pelajaran 2016/2017. 
Hal ini dapat dilihat dari rata-rata persentase hasil belajar siswa yang mengalami peningkatan sebesar (M\%) 10,22\% yaitu dari (M\%) 67,60\% yang berada dalam rentang nilai 55\% - 69\% dengan kategori sedang pada siklus I menjadi (M\%) 77,82\% yang berada pada rentang nilai 70\%-84\% dengan kategori tinggi pada siklus II. Bedasarkan simpulan yang diperoleh dalam penelitian tindakan kelas ini dapat diajukan beberapa saran sebagai berikut: 1) Kepada Para Guru, Disarankan agar menerapakan metode jigsaw dalam proses pembelajaran IPA. Mengingat hasil belajar yang dicapai dengan menerapakan metode jigsaw yang memadai membantu anak dalam membangun pengetahuan yang dapat diingat lebih lama, karena siswa mendapat pengalaman yang lebih bermakna; 2) Kepada Kepala Sekolah, Mengarahkan para guru agar senantiasa mempergunakan metode jigsaw dalam melaksanakan proses pembelajaran; 3) Kepada Siswa; 3) Dalam proses pembelajaran selalu mengikuti dan memperhatikan dengan sungguh-sungguh sehingga dapat menguasai materi pembelajaran dengan baik.

\section{Daftar Pustaka}

Angga Wiguna, Sang Gede., I Wayan Widiana, Dewa Nyoman Sudana. Penerapan Pembelajaran Berbasis Otak Untuk Meningkatkan Kemampuan Pemecahan Masalah Matematika Siswa Kelas V Sekolah Dasar. Mimbar PGSD Vol 5 No 2 Tahun 2016. (http://ejournal.undiksha.ac.id/index.php/JJPGSD/ article/view/7776).

Agung, A.A Gede. 2010. Metedologi Penelitian Pendidikan. Singaraja: Aditya Media Publishing.

Agusditya, Putu Handy., I.G.A.A. Sri Asri, I Made Suara. The Effect of Scientific Approach Based on Portfolio Assessment towards the Learning Outcomes of Civic Education of the Students Grade V Viewed from the Tendency of Observing Objects on Theme 7 SDN 4 Ubung. Journal of Evaluation and Research in Education (JERE) Vol 1 No 1 Tahun 2017. (http://ejournal.undiksha.ac.id/ index.php/JERE/article/view/9842).

Agus Suarimbawa, Kadek., A. A. I. N. Marhaeni, GAP Suprianti. 2017. An Analysis of Authentic Assessment Implementation Based on Curriculum 2013 in SMP Negeri 4 Singaraja. Journal of Evaluation and Research in Education (JERE) Vol 1 No 1 Tahun 2017 (http://ejournal.undiksha.ac.id/ index.php/JERE/article/view/9551).

Arends, R. I. 1997. Classroom Instruction and Management. Mc. Graw Hill Companies. United States of America.

Arikunto, Suharsimi. 2014. Penelitian Tindakan Kelas. Jakarta: Bumi Aksara.

Catharina T. dkk. 2004.Psikologi Belajar. Semarang: UPT MKK UNNES

Dimyati dan Mudjono, 2006.Belajar dan Pembelajaran. Jakarta: PT. Rineka Cipta.

Hisyam Zaini.2007. Srategi pembelajaran aktif. Yogyakarta: Insan Mandiri.

Ibrahim, Muslimin, dkk. 2002. Pembelajaran Kooperatif. Surabaya: Universitas Negeri Surabaya.

Irawatiardi, 2014 Langkah-Langkah Pembelajaran Kooperatif. http://Hasil Belajar .co.id. diakses pada tanggal 17 Desember 2014

Isjoni. 2007. Cooperative Learning Efektivitas Pembelajaran Kelompok. Bandung:Alfabeta.

Kagan, S. 1992 Cooperative Learning. San Juan Capistrano : Kagan Cooperative Learning.

Oka Sugiarta, Gst Pt., I Wayan Widiana, I Dewa Kade Tastra. Penerapan Model Pembelajaran Akselerasi (Accelerated Learning) Untuk Meningkatkan Hasil Belajar Ipa Siswa Kelas V di SD N 8 Banyuning. Mimbar PGSD Vol 6 No 3 Tahun 2016. (http://ejournal.undiksha.ac.id/index.php/JJPGSD/ article/view/8600).

Martinis Yamin. (2013). Strategi \& Metode dalam Model Pembelajaran. Jakarta: Referensi (GP Press Group)

Mazjun. (2009) Tujuan model pembelajaran, Kooperativehttp://www.mazjun.student. fkip.uns.ac.id/2009/10/16/modelpembelajarank ooperatif diakses tanggal 28 Januari 2011.

Muhibbin Syah. (2013). Psikologi Pendidikan dengan Pendekatan Baru. Bandung: PT Remaja Rosdakarya

Nur, Muhammad. 1999. Pengantar Filsafat Pendidikan. Malang: FIP IKIP Malang.

Nurkancana, Wayan dan Sunartana. 1990. Evaluasi Hasil Belajar. Surabaya: Usaha Nasional. 
Purwanto, Ngalin. 1989. Psikologi Pendidikan. Bandung: PT. Remaja Karya

Reynolds, J.M., 1997. An Introduction to Applied and Environmental Geophysics. New York:John Willey and Sons.

Rusman. (2012). Model-model Pembelajaran. Jakarta: PT. RajaGrafindo Persada

Samatowa, Usman. 2010. Pembelajaran IPA di Sekolah Dasar. Jakarta: PT. Indek.

Sudjana, Nana. 1990. Penilaian Hasil Proses Belajar Mengajar.Badung: Remaja Rosdakraya

Sudjana, Nana. 2010. Penilaian Hasil Proses Belajar Mengajar. Bandung: Sinar Biru.

Surakhmad, Winarno. 1997.Pengantar Penelitian Ilmiah Dasar Metode dan Teknik.Bandung :Tarsito.

Susilofi.(2010). Model Pembelajaran Kooperatif.http://www.Susilofi.wordpress.com/20 10/09/28/model-pembelajarankooperatif. diakses tanggal 01 -Februari 2011

Tirtaraharja, S. L La Sulo. 2005. Suluh Pendidikan. Tabanan: IKIP Saraswati

Widiana, I Wayan. 2016. Pengembangan Asesmen Proyek Dalam Pembelajaran IPA di Sekolah Dasar. Jurnal Pendidikan Indonesia Vol 6.No 2 tahun 2016. (http://ejournal.undiksha.ac.id/ index.php/JPI/article/view/8154). 